\title{
ALARM BELLS RING FOR THE CULTURAL HERITAGE OF ISTANBUL
}

\author{
HULYA BERKMEN \& SIRMA TURGUT \\ Department of Urban and Regional Planning, Yildiz Technical University, Turkey
}

\begin{abstract}
With a history that goes back 8500 years, Istanbul is located on top of the Bosphorus - a unique geographical beauty of the world that has hosted Roman, Byzantine and Ottoman Empires for decades as a bridge between European and Asian continents. These unique privileges of the geography almost witness the history, with the identity that it steals from the history itself. Ancient Istanbul, known as the "Historical Peninsula", was included in the UNESCO World Heritage List in 1985. The most important prerequisite for being included in the list is to document the "outstanding universal value" of the entity. Istanbul meets four of the required criteria for being included in the UNESCO World Heritage List. Unfortunately, the Historical Peninsula, as the precious core of Istanbul, is not properly "protected" based on scientific measures, although it does actually constitute an urban, historical and archaeological protected area. It possesses four World Heritage Areas inside its border, and there are Conservation Master Plans and Management Plans set in place for the area. Here, the mega-projects, investment decisions and applications that are being developed - ironically, with different plan decisions - are incompatible with the current protection policies and plan decisions most of the time. Consequently, this process threatens the World Heritage Sites in Istanbul today. This study elaborates upon the projects that are being conducted in the Historical Peninsula as a whole, looks in detail at the risks that they bring to the area, and demonstrates the dangers that the area is facing as a result of the Conservation Master Plans and Management Plan Decisions.

Keywords: Istanbul, cultural heritage, cultural heritage impact assessment, World Heritage Area, outstanding universal value.
\end{abstract}

\section{INTRODUCTION}

Istanbul, which has hosted empires throughout history, has been one of the most important settlements of the history of humanity, with unique values, such as the two continents on which it is situated, the Bosphorus and Golden Horn. The Historical Peninsula, on the other hand, is the most significant sub-region of Istanbul that witnessed this magnificent history. Hence, the Historical Peninsula has , in a way, acted as a summary of the history of Istanbul for thousands of years. It is possible to see the marks of the Egyptian era through to the Roman era, or the Byzantine era through to the Ottoman era, at the same time, together and on top of each other in this district. The Historical Peninsula (interior part of the city walls), which is the first region where Istanbul was founded, is located in the borders of the Fatih District, surrounded by the Golden Horn to the North, the Sea of Marmara to the South and the Bosphorus to the East. This region constitutes a transitional path between Asia and Europe, and has hosted settlements since the Palaeolithic, Neolithic and Bronze ages (Fig. 1).

The Historical Peninsula, which is also included in the World Heritage List, shelters the Historic Areas, which consist of four sub-regions: the Archaeological Park; Süleymaniye Mosque and its associated conservation area; Zeyrek Mosque (Pantocrator Church) and its associated conservation area; and the land walls of Istanbul (Fig. 1). 


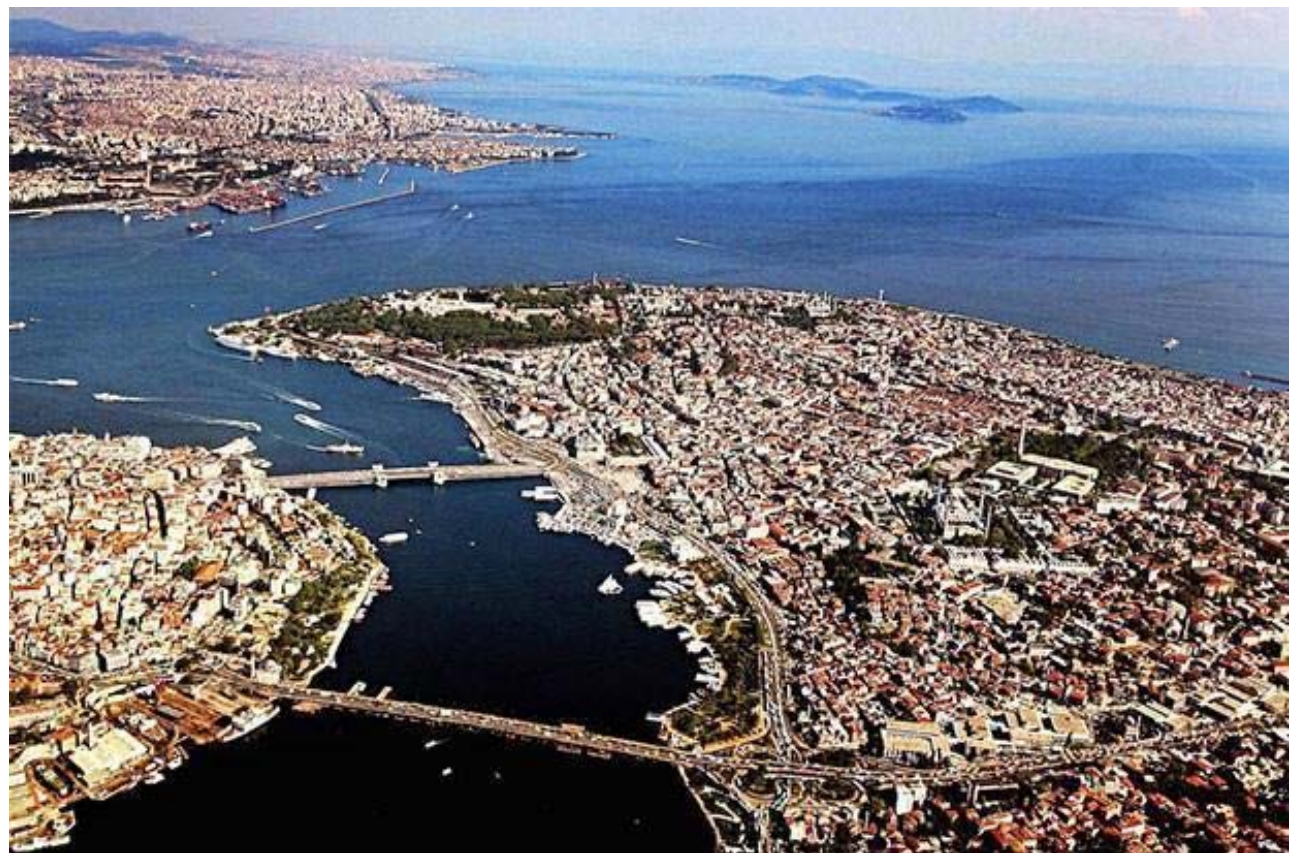

Figure 1: The Historical Peninsula.

2 CONCEPT OF A WORLD HERITAGE AREA AND ISTANBUL

The 17th General Conference of the United Nations Organization for Education, Science and Culture (UNESCO), which took place on 17 October-21 November 1972 in Paris, was held in order to introduce the cultural and natural protected areas that have outstanding universal value, accepted as the common heritage of humankind to the world, to raise awareness about the protection of the aforementioned universal heritage, and to provide the necessary collaboration to sustain the cultural and natural values that are getting lost. Here, it was accepted that these issues must be subject to an international convention. Thus, on 16 November 1972, the Convention Concerning the Protection of the World Cultural and Natural Heritage was approved, and a major step was taken in transferring the common cultural and natural values of the world's nations to the future generations, and to protect these assets on an international platform.

Under this convention, the entities that are created by different cultures and civilizations throughout history, and that illuminate the paths of different periods, stages, diversities and wealth of this common past, are under protection with the understanding that "loss of one will be loss of memory of all humankind". Again, with this convention, UNESCO drew attention to the threat of destruction of cultural and natural heritage, not only because of traditional deterioration reasons, but also because of the change in economic and social conditions. UNESCO, underscoring the fact that destroying or harming any part of a nation's cultural and natural heritage would be an irreversible poverty for the heritage of the world's nations, considers the protection of the world heritage that belongs to the entire humankind as a duty of the international community, and provides a basis for an effective system to protect and deliver the cultural and natural heritage that possess exceptional value, to the future generations, based on modern scientific methods. 
With the Convention, the parties undertook the duties of defining the inventory of the cultural and natural heritage entities inside their own borders, protecting them, presenting them, taking any required legal, administrative, scientific and technical precautions, and delivering them to the future generations.

According to the Convention, the cultural and natural entities that have "outstanding universal value" and that are guaranteed to be protected by the governments that possess them are called "world heritage" sites, and the list in which these entities are included is called the "World Heritage List" [1].

On 14 April 1982, Law no. 2658 was entered into force in order to allow Turkey to embrace the criteria that are defined in "The Convention concerning the Protection of World Cultural and Natural Heritage" that was accepted on 16 November 1972 by UNESCO, to provide the protection and transfer of cultural and natural values to the future generations, to promote our cultural and natural entities at the international level. With the decision of the Council of Ministers - the enactment of law no. 8/4788 on 23 May 1982, based on this law - Turkey became a part of "The Convention concerning the Protection of World Cultural and Natural Heritage" and presented the inventory of cultural and natural entities inside the borders of the country to the World Heritage Committee as a list.

Istanbul has hosted different religions and cultures at the most special meeting point of water and land, and carried diverse civilizations, monumental structures, examples of civil architecture, protected areas and cultural values from 8500 years ago through to today. This city, with a legendary silhouette and urban pattern, was registered on the UNESCO World Heritage List on 6 December 1985 under the name of the "Historic Areas of Istanbul", based on The Convention Concerning the Protection of World Cultural and Natural Heritage [2]. The "Historic Areas of Istanbul" are represented by four different sub-regions, as mentioned in the latter (Fig. 2).

These areas, which are important destinations for national and international tourism, and which are located inside the Historical Peninsula, are included in World Heritage List having met cultural criteria nos. (i)-(iv) out of the ten criteria that are provided in defining the entities that have outstanding universal value in the World Heritage List. These criteria are presented for the following reasons: (i) to represent a masterpiece of human creative genius; (ii) to exhibit an important interchange of human values, over a span of time or within a cultural area of the world, in relation to developments in architecture or technology, monumental arts, town planning or landscape design; (iii) to bear unique or exceptional testimony to a cultural tradition or to a civilization that is living or which has disappeared; and (iv) to be an outstanding example of a type of building, architectural or technological ensemble or landscape that illustrates a significant stage (or stages) in human history [3].

\section{CONSERVATION STATUS OF ISTANBUL'S HISTORICAL PENINSULA}

The four protection areas that were included in the World Heritage List in 1985 under the name of "Historic Areas of Istanbul" were initially registered as protected areas in the context of national legislation, before they were included in the list. As there were no integrated protected areas declared within the Historical Peninsula until 1995, for the first time, the "Topkap1 Palace and Sultanahmet Region" was declared as an "Archaeological park" in 1953; "Zeyrek Mosque and its Associated Conservation Areas" were protected under law in 1979; "Suleymaniye Mosque and its Associated Conservation Areas" were protected under law in 1977; and the "City Walls of Istanbul" were protected under law in 1981. Since then, it has been debated whether the areas that need to be protected outside of the World Heritage Areas in Istanbul's Historical Peninsula must be declared as "protected areas". 


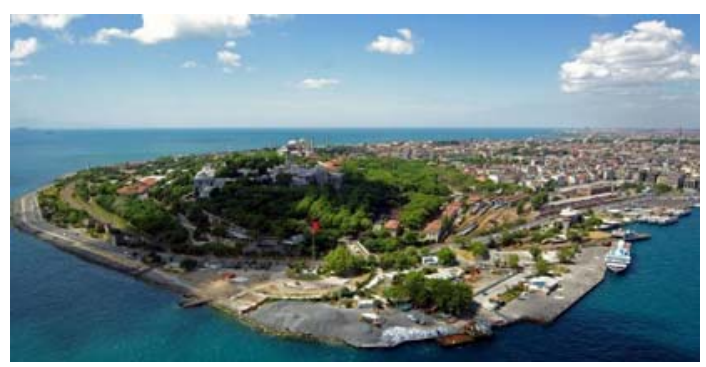

(a)

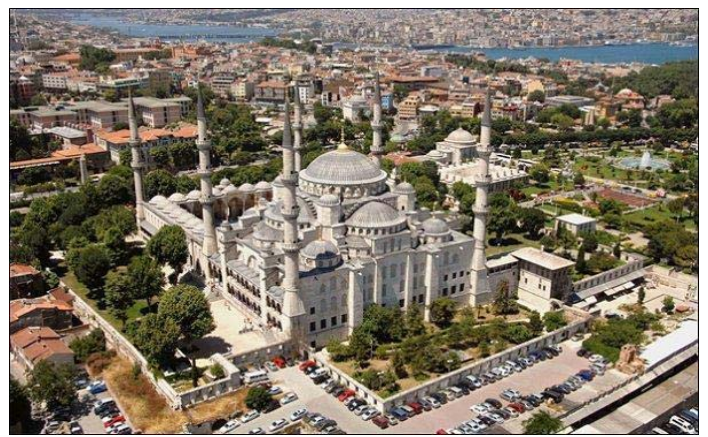

(b)

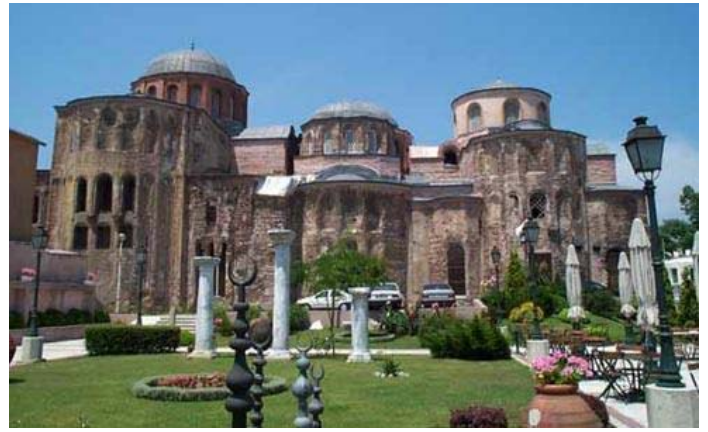

(c)

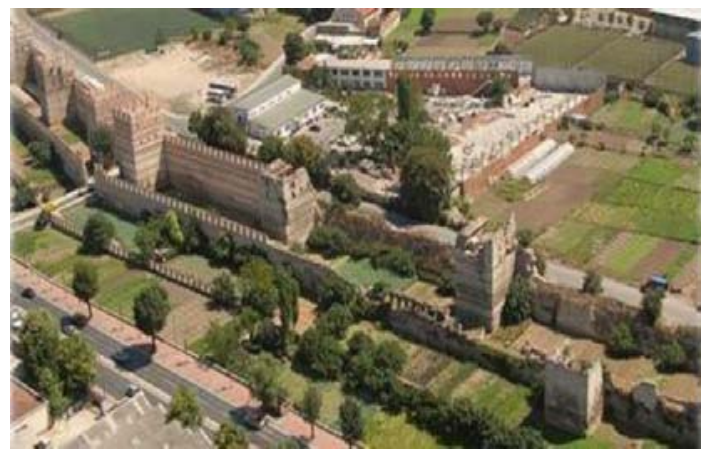

(d)

Figure 2: Historic Areas of Istanbul [4]. (a) Archaeological park; (b) Süleymaniye Mosque; (c) Zeyrek Mosque (Pantocrator Church); (d) Land walls of Istanbul. 
As a result of these studies, Istanbul's Historical Peninsula was declared a protected area and protected under law entirely in 1995, in the context of the Law on the Conservation of Cultural and Natural Properties, being part "archaeological", part "urban archaeological", and part "historical and urban" [5]. With this new status of protection, the studies for creating a conservation plan and defining an inventory that would cover all of Istanbul's Historical Peninsula were initiated.

Today, the inner part of the city walls, which we name the "Historical Peninsula", has been subjected to many planning studies. However, some of these studies have not yet had the chance to be enacted. A common objective of these plans is the conservation of the present tissue and silhouette of the area, which have an international and extremely unique significance.

The planning history of the Historical Peninsula is summarized as follows. The first planning study for the inner part of the city walls was made by Von Moltke in 1837. After that, Marie De Lavnay (1864), Carl Ch. Lörcher (1922-1928), Herman Elgötz (1933), Alfred Agache (1933), Jack H. Lambert (1933), Henri Prost (1936), Martin Wagner (1938) and Piccinato (1960) conducted various planning studies [6], [7]. After the 1960s, there were planning studies made by Turkish planners as well. The Gündüz Özdeş Plan (1990) and the plan that was made by local governments in 2005 were cancelled.

The final study, which was conducted in different eras, and which is still valid today, is the Fatih District Urban Protected Area Conservation Plan in scale of 1/5000. This plan was approved on 11 August 2011 with decision no. 4728. However, after the cancellation of the 1990 and 2005 plans, the area was left for a long time with no specific plan in place, and so it was managed based on "Transition Period Construction Orders" that were declared by the related conservation council, from 2008 to 2010 [8]. The Law on the Conservation of Cultural and Natural Property (no. 2863) made it mandatory to prepare Conservation Plans in the following year of the declaration of protected areas. However, in practice, there is no working example of a plan that has been completed in one year. Thus, the practices continue with the "construction status of a transition period". The main purpose of having the construction status of a transition period is to protect the construction rights of the inhabitants until the plans are completed, and to allow construction in a way that the construction/population density are below the probably/expected plan. However, since the preparation process of the plan takes a long time, and since the practices are executed under the construction status of a transition period, there are many contradicting decisions and harmful practices taking place, as well as an atmosphere of uncertainty. Most importantly, the development process is being led without an integrated plan in place. This has also augmented the lack of supervision and the amount of speculation involved. Creating a balance between transformation and protection in the Historical Peninsula is an extremely sensitive issue, and so the sustainability of balance and conservation is put in jeopardy [1]. However, there was another term that constituted a significant obstacle in the protection of the Historical Peninsula: "Renovation Areas". This term, which entered into the practice process with the Law on Conservation by Renovation and Use by Revitalization of the Deteriorated Historical and Cultural Immovable Property" no. 5366, approved in 2005, brought up the "renovation" issue for the protected areas, and, furthermore, it defined and authorized "Renovation Councils" as another type of institution that may approve plans, besides Protection Councils, who can be named as important actors in the process. There are 22 renovation areas in the Management Plan Area, declared within the context of Law no. 5366 and approved by the Council of Ministers. Some 21 of these renovation areas are in the Fatih District (Historical Peninsula), and one is in Zeytinburnu. In this way, the "renovation" and the "protection" councils that started to work separately and independently from each other, started to make decisions that contradicted 
each other, that could not be integrated and that had almost completely different objectives in the same field.

Another term that is very controversial, at a time when serious contradictions are occurring in this field, is "Area Management". The Operational Guidelines for the Implementation of the World Heritage Convention 1977, 2008, which is a guideline for applying the World Heritage Convention, states the following: "Each property must have a management plan or a management system that defines how to protect the outstanding universal value of the property with participatory methods. The purpose of this management system is to protect the property effectively for the generations of today and of the future". Starting from this point, a 2004 law and a 2005 Area Management Regulation gave the authority to make management plans in urban protected areas and metropolitan municipalities. Thus, the Presidency of the Historical Peninsula Area is authorized to make the Historical Peninsula Area Management Plan.

However, this process did not consist of studies that were accepted by the associated administrative unit, nor were they able to complete each other, provide any form of protection or be continuous; thus, a sufficient process for protecting the region was not developed.

\section{WHY DO ALARM BELLS RING FOR THE HISTROCAL PENINSULA?}

The Historic Areas of Istanbul are under legal protection with national legislation. However, there is not any special planning legislation in place to protect the World Heritage Areas. The responsibility of protection and sustainability of the area is distributed between central government (Ministry of Culture and Tourism, General Directorate for Cultural Heritage and Museums, Directorate General for Foundations), local governments and many other governmental institutions. Registered buildings, physical interventions to protected areas, and functional changes in the region are subjected to the approval of the Conservation Board. The Site Management Directorate for Cultural and Natural Sites of Istanbul was founded in 2006 within the scope of Istanbul's Metropolitan Municipality, in order to coordinate the processes of planning management for World Heritage Sites. The work of the Site Management Directorate for Cultural and Natural Sites of Istanbul is supported by a Consultative Committee and a Coordination and Supervision Committee. Furthermore, an Area Manager is assigned. Moreover, a unit for providing collaboration between the related institutions to apply World Heritage Convention and Practical Guide, for coordinating the administrative work of World Heritage Areas in Turkey in the scope of Ministry of Culture and Tourism, is also structured.

Thus, such a region that has long lacked any plan and that has developed its construction rights solely on a "parcel" scale, independently from the plan, is unable to develop in an integrated way. The "protection" and "renovation" councils that are authorized in the region were not able to provide integration between the objectives, or sufficient coordination between institutions like the "Area Presidency" and local governments.

Mega-projects, transportation and investment decisions that lack integration with planning decisions and protection principles created a significant threat for the conservation of the area.

Traffic loads, point design decisions and practices, gaps and inadequacies in supervision because of, for example, function decisions that are incompatible with the area, or construction/population densities that are brought about at "parcel" scales, put the sustainability of protection in jeopardy. 


\section{CONCLUSION}

The Historical Peninsula is an attraction, not only because of the remarkable buildings of cultural heritage it possesses, but also because of its close connection to its traditions, and its mystic identity that smells of spice in world tourism. As this colourful life spreads to any hour and space, the identity of the Historical Peninsula as a cultural centre gains dominance, besides its identity as an economical centre. The social structure, and its diversity in terms of functional areas, field usage, cultural and usage identity, structure typology, spatial tissue, etc., are just some of the elements that make the region unique. Thus, the "Management Plan", which is a term that is very important for the concept of and as a tool for protection in the Historical Peninsula, is crucial for the region.

The Historical Peninsula Management Plan shows the area's difference from other heritage areas of the world in terms of its magnitude at the scale of a city in total surface area, and its coverage of more than one heritage area. Moreover, the management plan is a relatively new concept in the scope of public institutions and other institutions.

The Historical Peninsula and Historic Areas of Istanbul, as a very special part of the common heritage of humankind, require a special understanding of management and protection because of their unique features. Although the protection work and practices in Turkey have a long history, they are unable to show scientific adequacy and they present a threat to the conservation of the area.

The required management and conservation conditions must be met in order to be included in the World Heritage List and to sustain outstanding universal value. The borders within the protection and government must be defined as features such as buffer zones, administrative systems, and sustainable usage [8]. Although these sub-insights and tools are defined in the area management studies, the inadequacies in coordination constitute an obstacle in facing the execution of a plan and the planning management processes successfully.

The lack of any present scientific structure or protection regulation, which perceives the discussions about developing urban management strategies, management plans, renovation actions, financial mechanisms for these actions, and social responsibility projects as a requirement, becomes a threat for the region from time to time. Important factors that contribute to these risks can be summarized as follows:

- The inadequacy of integrated approaches to planning, the lack of extensiveness in the conservation plans, the absence of coordination between the plans at different scales, and the lack of continuity of "protection policies".

- Planning decisions' loss of scientific consistency under political manipulations (political pressure, decisions, manipulations, etc.).

- Segmental and project-based approaches that carry targets that are incompatible with the upper-scale plans.

- The execution of planning tools that contradict the "protection" concept (urban transformation, functions that contradict protection, augmentation of the density, story heights, constructions that are incompatible with the city's silhouette).

- Central and local governments and decision units (such as the Related Ministry, Area Directorate, Conservation Committee, Local Governments) that are independent from each other, and that work independently, almost completely uninformed about each other's work.

- Imitator approaches in planning, projects and construction (destruction of the unique architectural pattern and identity).

- Poor restorations, inadequate support of the project systems and gaps in the supervision process of the practices. 
- The teams of experts involved in the protection processes and the academic knowledge that does not reflect on practice.

- The destruction of intangible cultural heritage (removal of Roman neighbourhoods).

Today, many projects that have occurred in the Historical Peninsula and the associated areas are perfect examples of these problems. Developments such as the Eurasia Bosphorus Transition, which is constructed entirely on the filling area in the Marmara shore of the region and which attracts a serious amount of traffic to the Historical Peninsula, the construction decisions that completely ruin the city's silhouette with rising buildings, and various function areas that are constructed on the filling areas, all exemplify these harmful practices (Fig. 3).

The project for "transforming the region into an attraction center", which the related local government often mentions, is solely based on real-estate development and/or area management. The decisions are mostly made behind closed doors and the legislations that are made based on these decisions continue to harm the "Historical Istanbul" in a way that contradicts "conservation policies". Recently, flagship projects such as "opportunity areas" or "urban transformation focuses", which are often mentioned by the central government, but are not openly elaborated for the citizens to hear, are other factors that would trigger the loss of the usage-protection balance of the region. With these developments, criteria like growth thresholds in story height and floor space of the constructions, which are extremely important for the region as a characteristic criterion and are starting to be left out or become distant from each other, or a scientific/objective mind that would embrace all of them, constitute a major obstacle in the face of the protection of the area in demonstrating developments that are based on subjective decisions.
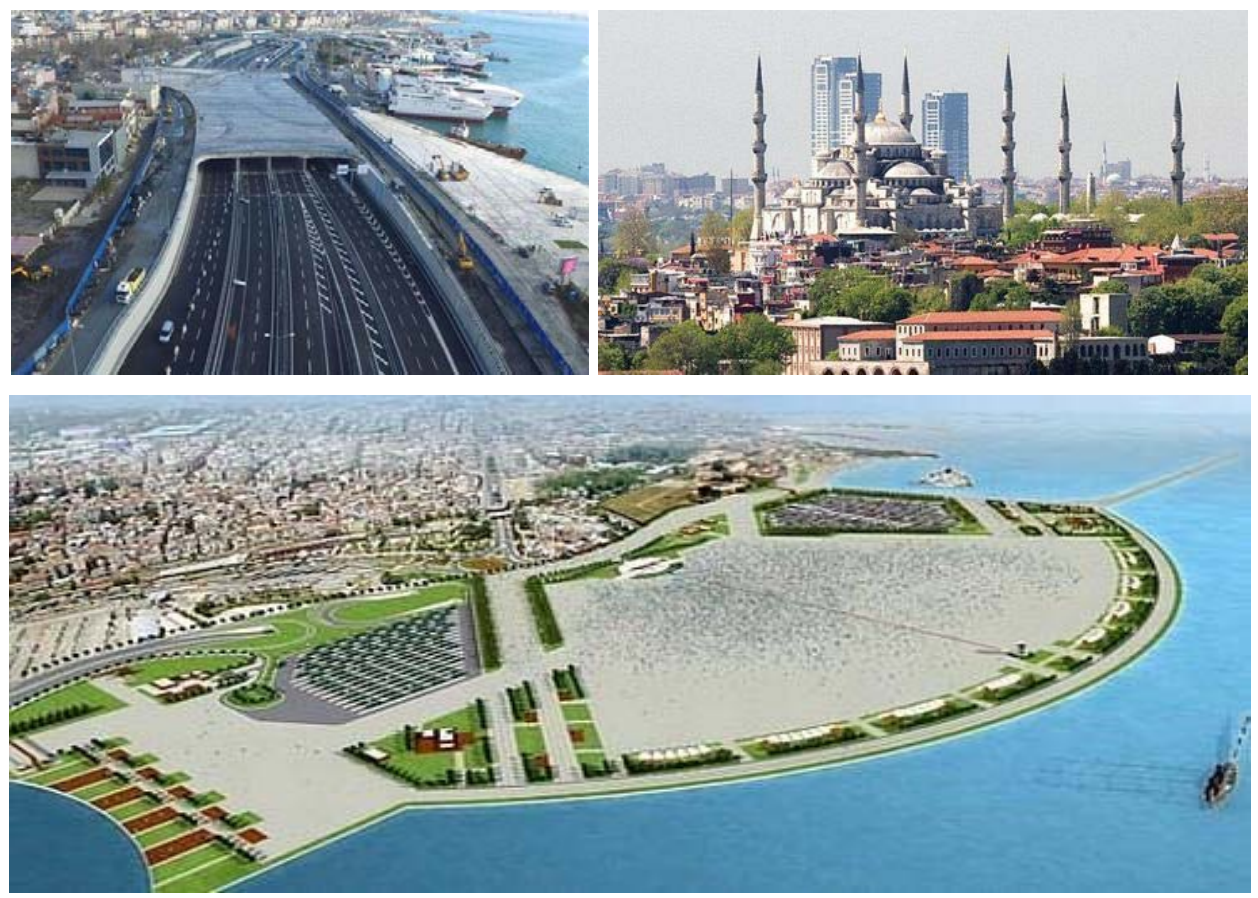

Figure 3: Examples of harmful practices that harm conservation concepts in the Historical Peninsula. 
The Historical Peninsula, which has universal value not only at the national level, but also at the supra-national level, must be able to protect all of the dynamics that it possesses in an intensive and sustainable way, and to deliver them to the future generations. In this context, the protection policies that are plotted under the light of common minds and science, application tools, government models, and integrated planning and application approaches, must be supported by the central and local governments and non-governmental organizations in terms of legal infrastructure and organizational structure.

\section{REFERENCES}

[1] UNESCO, World Heritage List. https://whc.unesco.org/en/list/. Accessed on: 8 Jul. 2018.

[2] UNESCO, Turkey - World Heritage List. https://whc.unesco.org/en/list/\&order =country\#alphaT. Accessed on: 8 Jul. 2018.

[3] Dünya Miras Listesi'ne Alınma Kriterleri. www.kulturvarliklari.gov.tr/TR,44439/ dunya-miras-listesine-alinma-kriterleri.html. Accessed on: 8 Jul. 2018.

[4] Alan Yönetim Planı Raporu, İstanbul Tarihi Alanları Alan Başkanlığı. www.alanbaskanligi.gov.tr/files/Y\%C3\%B6netim\%20Plan\%C4\%B1_24\%C5\%9Fub at2012 k.pdf. Accessed on: 30 Jun. 2018.

[5] Tarihi Yarımada Koruma Amaçlı İmar Planı Açıklama Raporu, İBB, pp. 36-37, 2011. www.ibb.gov.tr. Accessed on: 10 Jul. 2018.

[6] Çelik, Z., 19.yy. da Osmanlı Başkenti: Değişen İstanbul 3, Tarih Vakfı Yurt Yayınları: Istanbul, pp. 96-100, 2005.

[7] Aydemir, I., İki Fransız Mimarı Henry Prost ve August Perret'in İstanbul ile İlgili Çalışmları. Megaron, 3(1), 2018.

[8] Tarihi Yarımada Çalışma Raporları, Mimarlar Odası, Istanbul. www.mimarist.org/ calisma_raporlari/42_donem/9_05_TarihiYarimada.pdf. Accessed on: 10 Jul. 2018. 